\title{
Consumers' Perception, Attitudes and Intention to Purchase Celebrity Endorsed Food and Beverage Products in Kuala Lumpur
}

Abdul Rais Abdul Rahman, Che Nurainina Mohd Najib, Siti Nur' Afifah Jaafar, Mohaini Mohamed@Naba

To Link this Article: http://dx.doi.org/10.6007/IJARBSS/v11-i16/11220

DOI:10.6007/IJARBSS/v11-i16/11220

Received: 11 July 2021, Revised: 09 August 2021, Accepted: 25 August 2021

Published Online: 22 September 2021

In-Text Citation: (Rahman et al., 2021)

To Cite this Article: Rahman, A. R. A., Najib, C. N. M., Jaafar, S. N. A., \& Mohamed@Naba, M. (2021). Consumers' Perception, Attitudes and Intention to Purchase Celebrity Endorsed Food and Beverage Products in Kuala Lumpur. International Journal of Academic Research in Business and Social Sciences, 11(16), 91-101.

\section{Copyright: (C) 2021 The Author(s)}

Published by Human Resource Management Academic Research Society (www.hrmars.com)

This article is published under the Creative Commons Attribution (CC BY 4.0) license. Anyone may reproduce, distribute, translate and create derivative works of this article (for both commercial and non-commercial purposes), subject to full attribution to the original publication and authors. The full terms of this license may be seen at: http://creativecommons.org/licences/by/4.0/legalcode

Special Issue Title: Contemporary Issues in Tourism and Hospitality industry, 2021, Pg. 91 - 101 


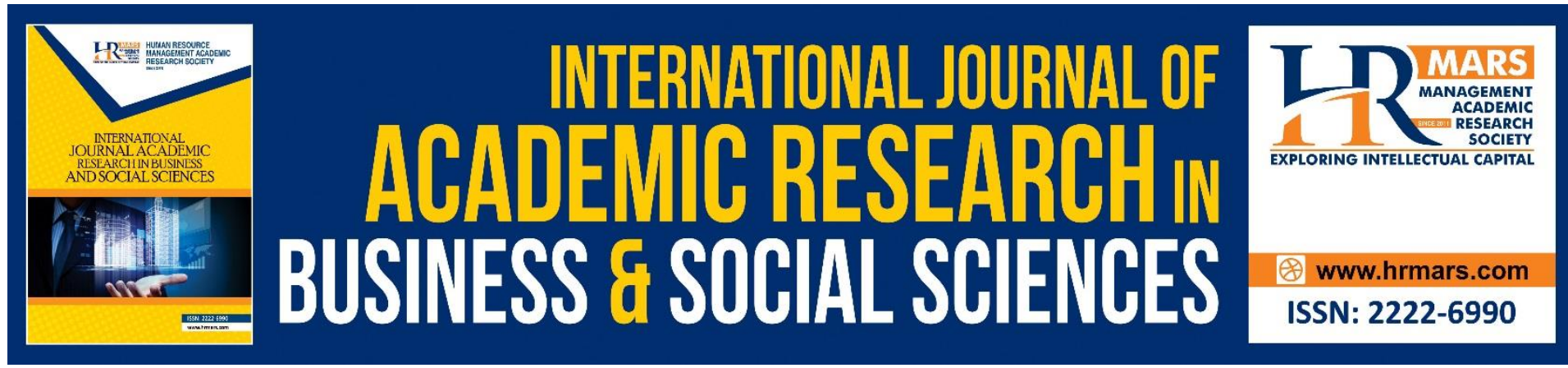

\title{
Consumers' Perception, Attitudes and Intention to Purchase Celebrity Endorsed Food and Beverage Products in Kuala Lumpur
}

\author{
Abdul Rais Abdul Rahman ${ }^{1}$, Che Nurainina Mohd Najib", Siti \\ Nur' Afifah Jaafar ${ }^{1}$, Mohaini Mohamed@Naba² \\ ${ }^{1}$ Universiti Malaysia Terengganu, Malaysia, ${ }^{2}$ Universiti Teknologi MARA, Terengganu Branch, \\ Malaysia \\ Email: hanee@uitm.edu.my
}

\begin{abstract}
Nowadays, consumers are well educated, diverse and technological-savvy thus it is a challenge to marketers to attract consumers' attention. Celebrity endorsement has been used to build credibility of the product, make the brand stand out, and open up new markets. Despite that, it is costly and during endorsement period, celebrity image could shine or tarnish the brand of the product. Thus, the study primarily investigates how consumers' perception and attitudes towards celebrity endorsement influence their purchase intention of celebrityendorsed food and beverage products in Kuala Lumpur. Survey by mean of self-administered questionnaire through purposive sampling was conducted among 120 respondents, in selected area in Kuala Lumpur. The data collected were then analysed to obtain descriptive statistic, correlation, and multiple linear regression. Purchase intention of celebrity-endorsed food and beverage products was found to be influenced by consumers' perception and attitudes. The finding indicated that positive perception and attitudes of consumers towards food products with endorsement could encourage repurchases. Food manufacturing companies could consider having celebrity endorsements for their products.
\end{abstract}

Keywords: Celebrity Endorsed Food Products, Consumer Perception, Consumer Attitude, Consumer Purchase Intention

\section{Introduction}

Celebrity endorsement is known effective marketing since the late $19^{\text {th }}$ century (Fletcher, 2008). They come from various background such as actor, actress, musicians, athletes and even politician. Millions of dollars are spend by companies in order to have celebrities appear in advertisements promoting particular products or services in both mass and social media platform which could assist to sustain the business in the long run (Gupta et al., 2015; Mukherjee, 2009).

Purchase intention refers to the preference of consumer in buying particular products or services because of the usefulness (Jamil \& Hassan, 2014). Three factors are known to 
influence consumers' purchase which includes perception towards credibility of celebrity endorser and consumers' attitude (Jamil \& Hassan, 2014; Mirabi et al., 2015; Chang, 2011). Perception towards the credibility of a particular celebrity endorser includes physical appearance, trustworthiness, and expertise greatly affected celebrity endorsement's effectiveness as it has a significant role on consumers' intention to purchase a particular products or services (Sertoglu et al., 2014). Ahmed et al (2012) contended that most of the times consumers are awed by the attractiveness of the celebrities which entices them to purchase a particular endorsed product. Consumer's purchase intention could also be triggered through consumers' attitude towards a product (Madahi \& Sukati, 2012).

Despite the rising trend of celebrity endorsement utilization in Malaysia, there is no information about consumers' perception and intention to purchase celebrity-endorsed food and beverage products. Several researches have attempted to measure the effect of celebrity endorsement on consumers' purchase intention and buying behaviour in general (Bailey, 2007; Chang, 2011; Zipporah \& Mberia, 2014). However, celebrity endorsed food and beverage products have yet to be explore extensively. Having identify the research gap, this study is aimed to fulfil the following objectives empirically:

R01. To study the relationship between perceived celebrity endorsement, perceived credibility of celebrity endorser, and consumers' attitude towards celebrity endorsed food and beverage products towards purchase intention of celebrity endorsed food and beverage products.

RO2. To determine the best predictor of consumers' purchase intention towards celebrityendorsed food and beverage products.

\section{Literature Review}

A review on the branded food and beverage products endorsed by celebrities in the USA from 1990 to 2017 revealed that there were 732 endorsements and the major 3 food and beverage products/brands having endorsements are snacks and candy, sugar-sweetened beverage and Quick Service Restaurant products (Zhou et al., 2019). Three categories of endorsement are; (1) endorsement involving particular food and beverage products (i.e. Coca-cola), (2) endorsement of the company or corporate brand (i.e. McDonald's) and (3) endorsement of health-promotion campaign brand also known as social marketing (Zhou et al., 2019). Their review depicted that food and beverage companies have been widely dependent on celebrity endorsement as marketing. Even a single brand such as Pepsi spend tens of millions to several pop singers and athletes (Rada \& Dominguez-Alvarez, 2014). This is because celebrity endorsement can benefit the industry in various ways, including increasing the consumers' awareness of their brands and thus may influence their intention to purchase the celebrityendorsed brands (Fathi \& Kheiri, 2015).

Consumer perception is concerned with how an individual selects, organizes, and interprets stimuli into what is happening in the real world (Schiffman \& Kanuk, 2000). Regarding celebrity endorsement, people's purchase decisions are influenced by the attractiveness and effectiveness of the celebrity endorser. The endorser's credibility can be defined as the degree to which they are considered believable, which is contributed by endorser's attractiveness, trustworthiness, and level of expertise (Ohanion, 1990). In other words, credibility is the audience's perception of the believability and truthfulness of the 
advertisement where products are being advertised (Wang, 2012). The attractiveness of endorsers is known to grab the attention of consumers to a specific product or brand through all means of advertisement (Zipporah \& Mberia, 2014). In advertising, trustworthiness is depicted as the level of confidence towards something that aims to communicate a valid, honest and objective manner (Choi \& Rifon, 2012). In a study among university students in Malaysia, a substantial link between credibility of celebrity endorsers and purchase intention was observed (Aziz et al., 2019). Trustworthiness of an advertising endorser is a major significant factor that impacts consumers' purchase intention (Rafique, 2012; Roozen \& Claeys, 2010). Expertise is about endorsers' professionalism in some specific knowledge which can convince consumers to buy products (Chanavat et al., 2016). Thus, it is crucial for companies to carefully select celebs who has adequate knowledge background associated with a specific product (Hugosson et al., 2014).

Attitude refers to an individual's internal assessment of a particular object and has been a crucial concept in marketing related studies since the 1960s (Sallam, 2011). Attitude is defined as positive and negative feelings (evaluative effect) of an individual in performing the target behaviour and is often considered relatively stable (Fishbein \& Ajzen, 1975). Consumers' attitude plays a crucial role in consumers' purchase intention and measuring the effectiveness of celebrity endorsed product (Bhatt et al., 2013; Madahi \& Sukati, 2012). In this study, attitudes towards celebrity endorsed food and beverage products are perceived as a susceptibility to respond in either a favourable or unfavourable manner to any food and beverage product involving celebrity endorsement.

Several studies investigated the purchase intention of celebrity endorsed food and beverages. Shenje (2017) found a positive and significant correlation amid celebrity endorsement and consumer buying intentions of fast food outlets. Meanwhile, Dutta and Singh (2013) revealed that the purchase of healthy foods brands by the Indian housewives also influenced by the celebrity endorsements. In another study, celebrity endorsement has less influence on the purchase intention of healthy food diet (Nugraha et al., 2018). These few examples show that celebrity endorsement may influence purchase intention, but the magnitude depends on types of product involved. This could be because consumers' perception towards celebrity as individual may influence their rating. For instance, Ohanion (1990), among the earliest researchers related to celebrity endorsement, revealed that a celebrity endorser's attractiveness, trustworthiness, and expertise influence consumers' purchase intentions for one celebrity but not for another celebrity. The proposed conceptual framework for this study is drawn as Figure 1 below based on the above discussion. 


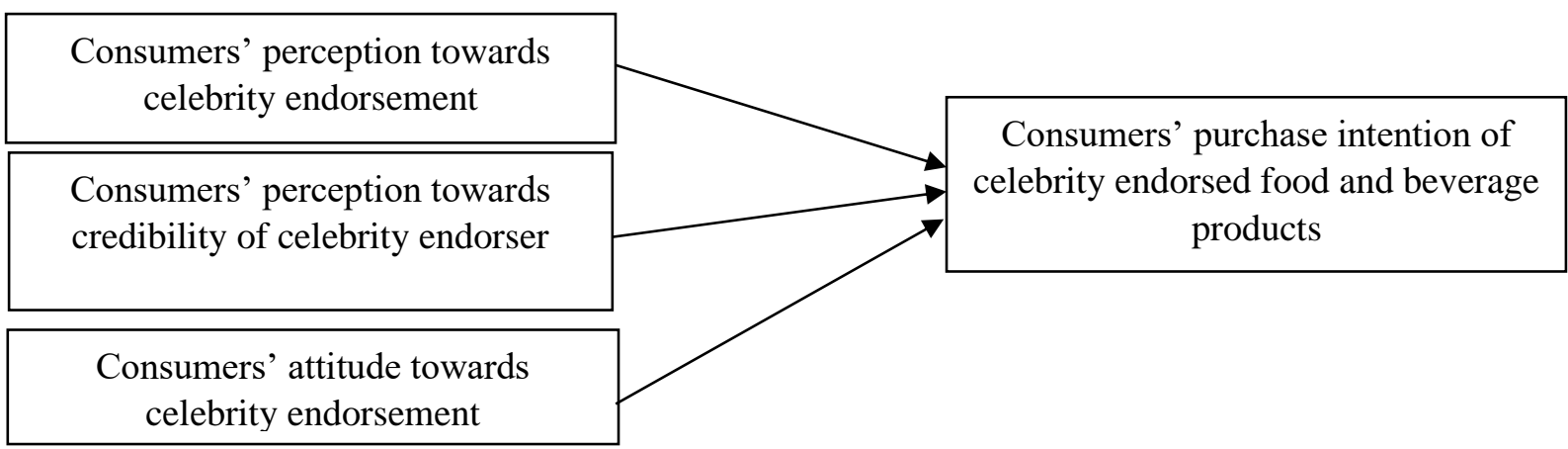

Figure 1: Conceptual framework adapted from Chang (2011); Samat et al. (2015); Zipporah and Mberia (2014)

In this study, three independent variables namely consumers' perception towards celebrity endorsement, consumers' perception towards credibility of celebrity endorser and consumer attitudes towards celebrity endorsed products are studied as factors that will potentially influence consumers' purchase intention.

\section{Methodology}

This study adopts a cross-section quantitative approach using structured questionnaires. Kuala Lumpur was chosen as sampling location because the outcome of the survey ranks Kuala Lumpur as the $23^{\text {rd }}$ city with the highest purchasing power in the world (Union Bank of Switzerland, 2012). Purposive sampling was used in selecting the supermarkets and sample size. Supermarket was chosen for sampling location because the object of this study i.e. food and beverage products can be found easily in supermarket. An information sheet consists of pictures of food products which have celebrity endorsement is presented to respondents. It assists the respondents to recall the products with celebrity endorsement before they complete the questionnaire. Prior to data collection, official approval letter was granted from the stores. Respondents were approached while they were shopping at the chosen stores. A screening question was asked to potential respondents.

Only consumers aged between 15 to 40 years who knew about the celebrity-endorsed food and beverage products became the subject for this study. Based on Youth Societies and Youth Development Act 2007 [Act 668], Malaysian youths' age range is between 15 to 40 years old. Using sample size calculation formula by Yamane (1967), the total number of respondents required is 120 considering the percentage of youth $48 \%$ within the total population of Kuala Lumpur 1.7 million (Department of Statistics Malaysia, 2015); Institute for Youth Research Malaysia ,2016). After getting consent from the potential respondents, a brief instruction on how to complete the questionnaire was given. Upon completion, token of appreciation was offered to respondents.

The structured questionnaire comprises of 6 sections namely Section A (Demographic Profiles), Section B (Consumers' Perception towards Celebrity Endorsement), Section C (Consumers' Perception towards Credibility of Celebrity Endorser), Section D (Consumers' Perception towards Characteristics of Celebrity-Endorsed Food Products), Section E (Consumers' Attitude towards Characteristics of Celebrity-Endorsed Food Products) and Section F (Consumers' Purchase Intention towards Celebrity-Endorsed Food Products). Items were adapted from past research relating to celebrity endorsed products and post purchase 
behaviour (Madahi \& Sukati, 2012; Preedanorawut et al., 2011; Samat et al., 2015; Ahmed et al., 2012; Chang, 2011; Nelson et al., 2012; Zipporah \& Mberia, 2014). Five-point Likert scale was used in measuring items in from section $B$ to $F$ ranging from $1=$ strongly disagree to $5=$ strongly agree. Questionnaire items are bilingual (Malay and English). A pilot study was carried out to authenticate the reliability and validity of measurement items.

The data were analysed using descriptive statistics in the Statistical Package for Social Science (SPSS) software version 21.0. The potential relationship between perceived celebrity endorsement, perceived credibility of celebrity endorser, product characteristics, and consumers' attitude towards purchase intention was tested using correlation analysis. Further examination to identify the most significant factor that influences consumers' purchase intention towards celebrity-endorsed food and beverage products was proceeded with multiple regression analysis. The basic threshold for regression models relating to sample size, normality, homoscedasticity, multicollinearity and outliers (Pallant, 2013) were met.

\section{Result and Analysis}

\section{Demographic Profile of Respondents}

A total of 120 completed questionnaires were obtained in this study. Majority respondents are female (62.5\%) compared to $37.5 \%$ of male respondents. $67.5 \%$ respondents aged between 15 to 26 years old while another $32.5 \%$ respondents are 27 to 40 years old. Malay became the highest proportion of respondents (87.5\%) compared to only $12.5 \%$ non-Malays participated in this study. $44.2 \%$ respondents attained degree or higher degree education while $40.8 \%$ respondents completed secondary education. The rest have attained primary education (3.3\%), STPM/matriculation/A-level (7.5\%) and other education (4.2\%).

\section{The Relationship between Independent Variables and Consumers' Purchase Intention of Celebrity Endorsed Food and Beverage Products}

Table 1 depicts the $r$ value for the relationship between the three relevant independent variables and consumers' purchase intention towards celebrity endorsed products.

Table 1: Relationship between all independent variables and consumers' purchase intention of celebrity endorsed food and beverage products.

\begin{tabular}{|l|l|l|}
\hline Variables & r value & $\begin{array}{l}\text { Strength of } \\
\text { relationship }\end{array}$ \\
\hline $\begin{array}{l}\text { Consumers' perception towards } \\
\text { celebrity endorsement }\end{array}$ & $0.528^{* *}$ & Moderate \\
\hline $\begin{array}{l}\text { Consumers' perception towards } \\
\text { credibility of celebrity endorser }\end{array}$ & $0.644^{* *}$ & Moderate \\
\hline $\begin{array}{l}\text { Consumers' attitudes towards } \\
\text { celebrity endorsement }\end{array}$ & $0.662^{* *}$ & Moderate \\
\hline
\end{tabular}

${ }^{* *}$ Correlation is significant at 0.01 level (2-tailed).

Table 1 indicates moderate to high correlation ( $r=0.528$ to 0.662 ) between all variables towards consumers' purchase intention of celebrity endorsed food and beverage products. This outcome is partly parallel to few past studies. Shenje (2017) found positive and significant correlations between celebrity endorsement and consumer buying intentions of fast food outlets. Both, Dutta and Singh (2013) and Nugraha et al. (2018) revealed the connection 
between celebrity endorsements and purchase intention of healthy food. Studies revealed the relationship between consumer attitudes to purchase intention (e.g. Bhatt et al., 2013; Madahi \& Sukati, 2012), but none has focused on food and beverage endorsed products. Study investigating all independent variables similar to this present study are yet to be found. Even within a similar country, research findings were varied because different variables were examined and dissimilarities in research design (e.g. Vien et al., 2017; Aziz et al., 2019). Results from this study somewhat has supported the fact that consumers' perception and attitudes towards celebrity endorsement and credibility of celebrity endorser may contribute to their intention to purchase food and beverage product with celebrity endorsement. This could be due to publics recognized celebrity endorsers very quickly thus can help specific products/brands stand out from the rest of the crowd and in turn could resulted in favorable attitudinal and behavioral responses (Doss, 2011).

\section{Determination of the Best Predictor that Influences Consumers' Purchase Intention towards Celebrity-Endorsed Food and Beverage Products}

Table 2 depicts the $R$ square, $\beta$ and $t$ value obtained from multiple regression analysis for the relationship between independent variables and consumers' purchase intention towards celebrity-endorsed food and beverage products.

Table 2: Result of multiple regression analysis

\begin{tabular}{|l|l|l|}
\hline Variables & $\begin{array}{l}\text { Beta } \\
\text { value }\end{array}$ & t value \\
\hline Overall perceived celebrity endorsement & 0.11 & 1.41 \\
\hline Overall perceived credibility of celebrity endorser & 0.04 & 0.47 \\
\hline $\begin{array}{l}\text { Overall consumers' attitude towards celebrity-endorsed } \\
\text { food and beverage products }\end{array}$ & 0.73 & $9.54^{*}$ \\
\hline $\mathrm{P}$ Value & $<0.001$ & \\
\hline $\mathrm{R}^{2}$ & 0.68 & \\
\hline
\end{tabular}

Note: ${ }^{*} p<0.01$

The $\mathrm{R}^{2}$ statistic depicts 68 percent of the total variance for the estimation of consumers' purchase intention towards celebrity-endorsed food and beverage products. In general, the bigger the $\mathrm{R}^{2}$, the greater the model fits the data (West et al., 2012). Consumers' attitude was the only significant predictor $(\beta=0.69, t=8.43)$ of consumers' purchase intention, despite correlation present between all independent variables and consumers' purchase intention (refer Table 2). It is probably because attitude is an established predictor of purchase intention for ages, conceptually and empirically. Ajzen (1991) developed the Theory of Planned Behaviour (TPB) in which is an extension to the Theory of Reasoned Action (TRA). This theory concurred that positive individual's attitudes and subjective norms will result in greater individual's behaviour control thus the more people are intended to perform the particular behavior (Ajzen, 2006). This theory has also supported finding in Table 3 which explains that consumers' intention to purchase that particular endorsed product is greatly influenced by his/her own attitude and the attitude of an admired celebrity towards the product or brand in the endorsement (Tran, 2011). 


\section{Conclusion}

This study suggests that consumers' perception of celebrity endorsement, consumers' credibility of celebrity endorser and their attitude towards celebrity-endorsed food and beverage products able to influence their purchase intention of celebrity-endorsed food and beverage products. Further investigation reveals that consumers' attitudes become the strongest predictor of purchasing of celebrity-endorsed food and beverage products. Thus, it is advocated that food marketers put more emphasis on developing consumers' positive attitudes towards the product to increase their chances of purchase intention. Food manufacturers must first understand that having good products is the utmost important criteria that leads to consumers' attitude. Marketers could then strategize ways to create consumers' positive attitudes towards the product, perhaps by changing their affect, behaviour, and beliefs. Celebrity may be involved in that attitude change strategy but be sure to select the right celebrities at business and consumers' perspective, who will be able to shine your brands and increase your sale.

Despite delivering some significant findings and insights, a few limitation could be improve upon in future studies. Firstly, responses were limited to only 120 respondents. Replicating the study on a state or national level will provide data to comprehend consumer perception, attitude, and purchase intention related to celebrity endorsed food products. Many consumer behaviour studies have extensively proved that the elements of perceived value, eating behaviour, and satisfaction develop a holistic understanding of the sequence of factors affecting post purchase behaviour. Therefore, future research focusing on post purchase behaviour of celebrity endorsed food products could incorporate some of these dimensions to develop an in-depth understanding.

\section{Acknowledgement}

The authors would like to thank participants who are directly or indirectly involved in ensuring that this research can be conducted well and completely done.

\section{Corresponding Author}

Mohaini Mohamed@Naba Universiti Teknologi MARA Campus Dungun

Email: hanee@uitm.edu.my

\section{References}

Sallam, A. M. A. (2011). The Impact of Source Credibility on Saudi Consumer's Attitude toward Print Advertisement: The Moderating Role of Brand Familiarity. International Journal of Marketing Studies, 3(4), 63-77.

Ahmed, A., Mir, F. A., \& Farooq, O. (2012). Effect of Celebrity Endorsement on Customers' Buying Behaviour; A Perspective from Pakistan. Interdisciplinary Journal of Contemporary Research in Business, 4(5), 584-592.

Ajzen, I. (1991). The theory of planned behavior, Organizational Behavior and Human Decision Processes, 50, $179-211$.

Ajzen, I. (2006). Constructing a theory of planned behavior questionnaire. Amherst, MA.

Aziz, Z. D. A., Omar, M. K., \& Ariffin, S. (2019). The Effects of Celebrity Endorsement towards Purchase Intention among Students in One Public University in Malaysia. International Journal of Academic Research Business and Social Sciences, 9(5), 498-507. 
Bailey, A. A., (2007). "Public Information and Consumer Scepticism Effects on Celebrity Endorsements: Studies among Young Consumers". Journal of Marketing Communications, 3(20),85-107.

Bhatt, N., Jayswal, R., \& Patel, J. (2013) "Impact of Celebrity Endorser's Source Credibility on Attitude towards Advertisements and Brands" South Asian Journal of Management, 20(4), 74-95.

Chanavat, N., Desbordes, M., \& Chadwick, S. (2016). Routledge handbook of sports development. London, Routledge.

Chang, L. (2011). Factors Influencing Changsha Teenager's Purchase Intentions towards Celebrity Endorsed Apparel. Graduate School of Business Journal, 4(2), 37-46.

Choi, S. M., \& Rifon, N. J. (2012). It is a match: The impact of congruence between celebrity image and consumer ideal self on endorsement effectiveness. Psychology \& Marketing, 29(90), 639-650.

Department of Statistics Malaysia. (2015). Federal Territory of Kuala Lumpur [online]. Available from https://www.statistics.gov.my/. [Acessed on 9 May 2016].

Doss, S. (2011), The transference of brand attitude: the effect on the celebrity endorser, Journal of Management and Marketing Research, 7(1), 58-70.

Dutta, K., \& Singh, S. (2013). Healthy Food Behavior and Celebrity Endorsement for Healthy Food Brands: A Study of Indian Housewives. The IUP Journal of Brand Management, 10(3), 33-46.

Fathi, F., \& Kheiri, B. (2015). Celebrity Endorsement and Its Effect on Consumer Behavior: A Literature Review. International Journal of Review in Life Sciences, Vol.5 No.10, pp. 619626.

Fishbein, M., \& Ajzen, I. (1975). A Bayesian Analysis if Attribution Processes. Psychological Bulletin, Vol. 82, No. 2, 261-277.

Fletcher, W. (2008). Powers of persuasion: The inside story of British advertising: 19512000. Oxford, Oxford University Press.

Gupta, R., Kishore, N., \& Verma, D. P. S. (2015). Impact of Celebrity Endorsement on Consumers' Advertisement Perception: A Study of Indian Consumers. British Journal of Marketing Studies, 3(8),34-49.

Hugosson, O., Matthys, C., \& Phung, L. (2014). Perception of the Celebrity Endorser: A study of how age and gender influences the consumer perception.

Institute For Youth Research Malaysia. (2016). Official Website of Institute For Youth Research Malaysia [online]. Retrieved from http://www.iyres.gov.my /index.php/ms/ siapakahbelia. [Accessed on 13 April 2016]

Jamil, R. A., \& Hassan, S. R. (2014). Influence of celebrity endorsement on consumer purchase intention for existing products: a comparative study. Journal of Management Info, 4(1),1-23.

Madahi, A., \& Sukati, I. (2012). The effect of external factors on purchase intention among young generation in Malaysia. International Business Research, 5(8), 153-159.

Mirabi, V., Akbariyeh, H., \& Tahmasebifard, H. (2015). A Study of Factors Affecting on Customers Purchase Intention. Journal of Multidisciplinary Engineering Science and Technology (JMEST), 2(1), 267-273.

Mukherjee, D. (2009). Impact of Celebrity Endorsements on Brand Image. SSRN Working Paper Series. Available at SSRN: http://ssrn.com/abstract1/41444814 or http://dx.doi.org /10.2139/ ssrn.1444814 (Accessed 10 December 2012). 
Nelson, O., Tunji, O., and Gloria, A. (2012). The dysfunctional and functional effect of celebrity endorsement on brand patronage. Online Journal of Communication and Media Technologies, 2(2) 141-152.

Nugraha, R., Kusumawardani, K. A., \& Octavianie, V. (2018). The influence of celebrity endorsement in Instagram towards customer behavior and purchase intention in healthy food diet business. Firm Journal of Management Studies. 3(2),1-24.

Ohanian, R. (1990). Construction and validation of a scale to measure celebrity endorsers. Perceived expertise, trustworthiness, and attractiveness. Journal of Advertising, 19(3), 39-52.

Pallant, J. (2013). SPSS survival manual: A step by step guide to data analysis using SPSS for Windows ( $5^{\text {th }}$ Ed.). Berkshire, England: McGraw-Hill Education.

Preedanorawut, S., Tang, X. H., \& Nguyen, P. N. (2011). Effectiveness of Consumer Endorser in Social Media Advertisement- Impact on consumers' attitudes and behaviors.

Retrieved from http://lup.lub.lu.se/student-papers/record/1982660

Rada, V. D., Dominguez-Alvarez, J. A. (2014). Response Quality of Self Administered Questionnaires: A Comparison between Paper and Web Questionnaires. Soc. Sci. Comput. Rev. 32(2),256-269.

Rafique, M. (2012). Impact of celebrity advertisement on customers' brand perception and purchase intention. Asian Journal of Business and Management Sciences, 1(11), 53-67.

Roozen, I., \& Claeys, C. (2010). 'The Relative Effectiveness of Celebrity Endorsement for Print Advertisement. Review of Business and Economic Literature, 55(1), 76-90.

Samat, M. F., Hashim, H., \& Yusoff, R. N. R. (2015). Endorser Credibility and Its Influence on the Attitude toward Social Media Advertisement in Malaysia. Review of Integrative Business and Economics Research, 4(1), 144-159.

Schiffman, L. G., \& Kanuk, L. L. (2000). Consumer behaviour (7th ed.). New York: Prentice Hall. Sertoglu, A. E., Catl, O., \& Korkmaz, S. (2014). Examining the Effect of Endorser

Credibility on the Consumers' Buying Intentions: An Empirical Study in Turkey. International Review of Management and Marketing, 4(1), 66-77.

Shenje, J. (2017). Midas touch or time bomb? A look at the influence of celebrity endorsement on customer purchase intentions: The case study of fast foods outlet companies in Harare, Zimbabwe. African Journal of Business Management. Vol. 11(15), 347-356.

Tran, L. M. L. (2011). The Persuasiveness of Celebrity Endorsement with Celebrities from the In-Group and Out-Group. Master Dissertation. Tilburg University, Netherlands.

Union Bank of Switzerland. (2012). The most expensive and richest cities in the world. City Mayors. [online] Available from http://www.citymayors.com/economics/usbpurchasing-power.html [Accessed on $1^{\text {st }}$ October 2016].

Vien, C. V., Yun, C. T., \& Fai, P. L. (2017) The effect of celebrity endorsement on brand attitude and purchase intention. Journal of Global Business and Social Entrepreneurship (GBSE). $1(4), 141-150$.

Wang, X. (2012). Attitude toward the Advertising and Subjective Norm on Purchase Intention: A Case of Television Advertising of Beauty and Personal Care Products in Bangkok. Doctoral dissertation, University of the Thai Chamber of Commerce, Thailand.

West, S. G., Taylor, A. B., \& Wu, W. (2012). Model fit and model selection in structural equation modeling. Handbook of Structural Equation Modeling, 1, 209-231.

Yamane, T. (1967). Statistics, An Introductory Analysis, 2nd Ed., Harper and Row, New York. 
Zhou, M., Rajamohan, S., Hedrick, V., Patiño, S. R-G., Abidi, F., Polys, N., \& Kraak, V. (2019). Mapping the Celebrity Endorsement of Branded Food and Beverage Products and Marketing Campaigns in the United States, 1990-2017. Int. J. Environ. Res. Public Health, 16(19), 3743.

Zipporah, M. M., \& Mberia, H. K. (2014). The Effects Of Celebrity Endorsement in Advertisements. International Journal of Academic Research in Economics and Management Sciences, 3(5), 178-188. 